tion tubes and six ordinary vegetative cells were isolated from one of these cultures. Single-cell cultures were grown from them and tested for their mating capacicy. As seen from the table, out of five cells with copulation tubes, four gave a (t) mating reaction and one a $(-)$ reaction; likewise, of the six vegetative cells, one gave a (+) mating reaction and five a (-) reaction.

\begin{tabular}{|c|c|c|c|}
\hline $\begin{array}{c}\text { Nature } \\
\text { of cells } \\
\text { isolated }\end{array}$ & $\begin{array}{c}\text { No. of } \\
\text { cells } \\
\text { isolated }\end{array}$ & $\begin{array}{c}\text { No. of single } \\
\text { cells showing a }(+) \\
\text { mating reaction }\end{array}$ & $\begin{array}{c}\text { No. of single } \\
\text { cells showing a }(-) \\
\text { mating reaction }\end{array}$ \\
\hline $\begin{array}{c}\text { Ceils with } \\
\text { copulation } \\
\text { tubes } \\
\text { Vegetative } \\
\text { cells }\end{array}$ & 5 & 4 & 1 \\
\hline
\end{tabular}

The facts that each of the single-cell progenies from the single-spore culture gives mating reaction with only one of the two tester strains, and that progenies from some cells prove to be $(+)$ and from others (-), show that the mating responses of these stocks with both the tester strains were due, not to loss of mating discrimination, but to the creation of cells of opposite mating type within the culture through mutation ${ }^{2}$. The simultaneous existence of. both types of cells in the culture results in the production of copulation tubes and zygotes in these stocks; and when they are tested with the tester strains, $(+)$ cells in the culture produce copulation tubes on crossing with $(-)$, and $(-)$ cells on crossing with $(+)$. This explanation seems more plausiblo than to assume the same cell on different occasions will respond to both as a result of loss of discriminatory power.

Department of Botany,

M. AHMad

University of Dacca,

Pakistan.

Feb. 26.

${ }^{2}$ Lindegren, C. C., and Lindegren, G., Ann. Mo. Bot. Garden, 31, $203(1944)$.

${ }^{2}$ Ahmad, M., Ph.D. thesis, Cambridge University (1948); Annals of Botany (in the press).

\section{Edmond About and the Technique of Freezing and Drying Tissues}

THE procedure of freezing and drying tissues for the purposes of histology is commonly known as the Altmann or Altmann-Gersh method. Altmann published his method in $1890^{1}$, and Gersh, in $1932^{2}$, described fundamental improvements in the technique. It is curious that in 1862 the basic principles of the method were described in "L'homme à l'oreille cassée", a scientific romance by Edmond About, an English translation of which was available in 1867.

About describes how the frozen body of a French prisoner was carefully dehydrated in vacuo over sulphuric acid and calcium chloride and preserved by a German man of science during the Napoleonic Wars. The technical detail given by About is very plausible; he describes how the quality of the freezing was checked by observing the perfect preservation of the red blood cells. This is a test that I personally used before reading the book.

I have not been able to discover any information as to the extent of About's scientific training, and any suggestions as to the source of his ideas can be only speculation. The discovery of the technique of frozen sectioning is given by $\mathrm{Mann}^{3}$ as 1842, and it is possible that About knew of this technique and improved on it for his story. It is also possible that he was elaborating the legends of bodies being recovered from glaciers.

It is a pleasing speculation to suggest that a German histologist may possibly have obtained the idea for a fundamental technique from reading a scientific romance.

$I$ am indebted to Dr. Henri Firket for bringing the book to my notice.

$$
\begin{gathered}
\text { Zoology Department, } \\
\text { King's College, } \\
\text { London, W.C.2. } \\
\text { July } 30 .
\end{gathered}
$$
1 Altmann, R., "Die Elementarorganism und ihre Beziehungen zu

${ }^{2}$ Gersh, I., Anat. Rec., 53, 309 (1932).

${ }^{3}$ Mann, G., "Physiological Histology" (Oxford, 1902).

\section{Terminology applied to Computing Machines}

MAY I suggest that a protest is overdue against the anthropomorphic character of the terminology that is being applied to electronic digital computors? To the layman the use of such a terminology seems to ascribe human or near-human properties to these machines. Not only is it undesirable to use such terms, but also it is quite unnecessary, as alternative engineering terms are well established.

Those who describe electronic digital computors often use the term 'instruction', for example, when speaking of what is done to the machine by the operator. 'The word 'teaching' has even crept in. In engineering, the words 'setting' or 'adjustment' have exactly the same meaning. Why not use them? Numbers associated with these devices are given the name 'information' where the established term is 'readings'. Enthusiasts for electronic digital computors speak of the 'memory' of these machines; engineers would, instead, speak of 'records' or 'stores'. For the symbols that represent numbers in the mechanism, again, these enthusiasts have introduced the term 'machine language' where an engineer would say 'code'. Perhaps worst of all, a predetermined sequence of events in a digital electronic computor has been spoken of as a 'decision' of the machine.

Biologists and other men of science are careful to warn against anthropomorphic interpretations of animal behaviour. They avoid the word 'decision' when speaking of animals lest it convey to the lay public the suggestion that the animal's powers of volition resemble those rightly or wrongly assumed when the word is applied to human affairs. They are right, for many fallacies are rooted in anthropomorphic habits of thought. Is it wise, then, to encourage the lay public to believe that electronic digital computors possess rudimentary powers of scholarship, reasoning and volition, and that they may be thought about in a way that would be deprecated if applied to lower animals? There is abundant evidence that, aided by the new unfortunate terminology, such a notion is being spread. Hence this protest.

"Gardole",

Reginald O. KaPP

Stanhope Road,

Croydon, Surrey. 